\title{
Removal of Copper(II) Ions from Aqueous Solutions by Hydroxyapatite-Based Materials Prepared from Eggshells
}

\begin{abstract}
CLAUDIA MARIA SIMONESCU, ALINA MELINESCU*, MARIA CIUCA, BIANCA ZARNESCU
University Politehnica of Bucharest, Faculty of Applied Chemistry and Materials Science, 1-7 Polizu Str., 011061 Bucharest, Romania

The experimental study aimed to establish the potential applications of the nano- and micrometric powders of hydroxyapatite in the removal processes of Cu(II) ions from synthetic aqueous solutions. For this purpose, hydroxyapatite (HAP) was used in the form of: 1) nanometric powder (labeled nano-HAP), and 2) calcium alginate hydroxyapatite composite microparticles (nicro-HAP-CaAlg). Eggshells have been used as a raw material to obtain HAP. The contact time, $\mathrm{pH}$ and $\mathrm{Cu}(\mathrm{II})$ concentration in the initial solution have been the main process variables with influence on the CU(II) ions removal by HAP samples. For both HAP based materials, an optimal $\mathrm{pH}$ value of 5 has been established. The nano-HAP powder has a higher $\mathrm{Cu}(\mathrm{II})$ adsorption capacity than micro-HAP-CaAlg based on the specific surface area values of nano-and micrometric powders. The adsorption isotherm experiments showed that this process can be described using Langmuir model according to which the adsorption takes place as a monolayer process on an homogeneous surface. The kinetic study revealed that the sorption process of $\mathrm{Cu}(\mathrm{II})$ from synthetic aqueous solutions can be described using the pseudo-second order kinetics model according to which the rate-determining step is chemisorption. The values of the retention capacity recommends both powders tested (nano-HAP and micro-HAP-CaAlg) to be used in the Cu(II) loaded water treatment process.
\end{abstract}

Keywords: hydroxyapatite nanopowder, calcium alginate-hydroxyapatite composite, copper removal, adsorption isotherm, kinetic studies, hydroxyapatite from egg shell

The presence of heavy metal ions in water is an important issue because of the harmful effects they have on flora, fauna, and human health. The current environmental legislation on environmental quality control is becoming increasingly stringent, and the discharge of wastewater containing heavy metals in drinking water sources is very well controlled. As a result, various methods of removing them from water were tested.

Copper is widely found in food, fruit and water. Drinking water brings some of the daily body's need for copper. Copper is an indispensable element of life, which helps the body to use iron in the blood. Consumption of $\mathrm{Cu}(\mathrm{II})$ in large amounts causes various health problems such as central nervous system damage, Wilson disease and gastrointestinal disorders [ 1-7]. Therefore, more and more attention has lately been paid on developing new, effective, and low cost processes to remove copper ions from wastewater [8 - 11].

In comparison with traditional systems for heavy metal ions removal from wastewater, such as ion exchange, adsorption, precipitation, ion flotation, membrane processes, the application of mineral materials is more attractive due to their higher chemical activity and biological stability [12]. Calcium hydroxyapatite (HAP) is known as a good material to remove heavy metal ions from wastewater because of its crystal structure, high oxidation/ reducing stability, high ability to immobilize contaminants, and reduced water solubility.

Various methods, such as precipitation [13], hydrothermal/solvothermal technique [14], sol-gel synthesis [15], microwave method [16], biosynthesis [17], mechanochemical synthesis [18], double interfacial diffusion method [19], the surfactant-assisted approach [20], ultrasonic synthesis [21] have been developed to prepare HAP. To avoid mineral depletion, many natural resources have been processed to produce HAP. Over the past years, the biogenic (natural) materials, such as shell [22], fish scale [23], eggshells [18], chicken bone [24], fish bone [25], clam and mussel shell [26] have been transformed into valuable biomaterials such as HAP. Industrial waste such as phosphogypsum (PG) [27], calcium sulfite waste [28], industrial desalinated brines [29], flue gas desulfurization (FGD) gypsum [30] have also been converted into HAP with important properties.

Synthetic compounds based on hydroxyapatite have numerous applications in the field of ceramic biomaterials, as adsorbents in chromatography for the separation of proteins and enzymes, or catalysts in dehydration, and dehydrogenation of alcohols, oxidation of methane. These applications are based on structural and surface characteristics of hydroxyapatite such as types of functional characteristics, acidity/basicity characteristics, surface loads, hydrophilicity and porosity. An effective method of inerting heavy metal ions is to bind them under the form of insoluble salts which can not be washed by water.

The preparation method, calcium source and experimental conditions strongly control the chemical and physical properties of hydroxyapatite, which are closely related to chemical reactivity and to adsorption properties.

The eggs are raw materials for the food industry, for sweet shops and for the hatching industry. Lately, they have been used in huge quantities, and, as a result, producing large quantities of eggshells as waste. This waste favors microbial growth and causes problems regarding environmental pollution. A significant way to recycle them is using them as precursor material for HAP synthesis [31, 32]. The major advantage of using eggshells to produce HAP is the fact that they contain natural trace elements such as $\mathrm{K}, \mathrm{Na}, \mathrm{Mg}, \mathrm{Sr}$ and Si which will be incorporated in

\footnotetext{
* email; alina.melinescu@gmail.com
} 
the crystalline structure of HAP and make it more compatible to human bone [33]. HAP prepared from eggshell exhibited osteoconduction and superior sinterability when compared to HAP from other sources [33].

The present experimental study aims to present imobilization of $\mathrm{Cu}(\mathrm{II})$ ions onto two porous materials (nanohydroxiapatite and calcium alginate hydroxyapatite composite) derived from eggshell. The influencing factors, adsorption mechanism and adsorption isotherms have been studied.

\section{Experimental part}

\section{Materials and equipments}

Alginic acid sodium saltfrom algae and calcium chloride purchased from Sigma Aldrich has been used to produce HAP composite. $1000 \mathrm{mg} / \mathrm{L} \mathrm{Cu}(\mathrm{II})$ stock solution has been prepared by dissolving $3.8020 \mathrm{~g} \mathrm{Cu}\left(\mathrm{NO}_{3}\right), 3 \mathrm{H}_{2} \mathrm{O}$ (Merck) in $\mathrm{IL}$ distilled water. Serial dilution of $1000^{2} \mathrm{mg} / \mathrm{L} \mathrm{Cu}(\mathrm{II})$ solutions have been performed to make the solutions with the desired concentrations. Solutions of $\mathrm{HNO}_{3}$ and $\mathrm{NH}_{4} \mathrm{OH}$ of different concentrations have been purchased from Merck Chemical. All the substances were analytical grade and they were used as received without further purification.

The synthesis of hydroxyapatite from unconventional raw materials was attempted. This study proposed to use of egg shells as a precursor, as many literature studies have shown that its can be used as a natural biosorbent, so that contaminated water can be cleansed by various unwanted species including heavy metals or organic dyes. After washing, milling, drying and calcination, egg shells become an important source of $\mathrm{CaO}$ (about $97 \%$ mass $\mathrm{CaO}$ ). By wet synthesis, $\mathrm{CaO}$ is converted to $\mathrm{Ca}(\mathrm{OH})_{2}$, then by reaction with a $85 \% \mathrm{H}_{3} \mathrm{PO}$ conc. solution, on a magnetic stirrer for $10 \mathrm{~min}$, followed by a $30 \mathrm{~min}$ microwave field treatment, then calcination at $200-300^{\circ} \mathrm{C}$, a nanometric hydroxyapatite powder with a medium particle size between 20 and $32 \mathrm{~nm}$ is obtained.

For the purpose of composite obtaining, $2 \mathrm{~g}$ of alginic acid sodium salt have been disolved in $100 \mathrm{~mL}$ of distilled water. After dissolution, $2 \mathrm{~g}$ of HAP derived from eggshell have been added to alginic acid sodium salt solution and stirring for $3 \mathrm{~h}$ at room temperature and $500 \mathrm{rpm}$. With the help of a syringe, the suspension containing HAP has been poured into a $\mathrm{CaCl}_{2}$ solution prepared from $4 \mathrm{~g}$ of $\mathrm{CaCl}_{2}$ and $200 \mathrm{~mL}$ distilled water. The micro-HAP-CaAlg prepared have been maintained for $2 \mathrm{~h}$ in contact with $\mathrm{CaCl}_{2}$ solution and after that they were washed with distilled water and dried at $60^{\circ} \mathrm{C}$ for $8 \mathrm{~h}$.

To immobilize $\mathrm{Cu}(\mathrm{II})$, batch experiments were carried out at room temperature using a GFL 3015 orbital shaker at a speed of $150 \mathrm{rpm}$.

The quantitative determination of $\mathrm{Cu}(\mathrm{II})$ ions before and after the retention process was performed by spectrometric method using an Analyst 400 Atomic Absorption Spectrometer produced by Perkin Elmer (USA).

To perform the experiments, $0.025 \mathrm{~g}$ of HAP samples were used which were keptin contact with $25 \mathrm{~mL}$ of $\mathrm{Cu}(\mathrm{II})$ ion solution and stirred at various times at room temperature at $150 \mathrm{rpm}$. Subsequently, the samples were filtered to determine the residual $\mathrm{Cu}(\mathrm{II})$ ion concentration.

For the study of the influence of $\mathrm{pH}$ on the retention capacity of $\mathrm{Cu}(\mathrm{II})$ ions from aqueous solutions, solutions of $\mathrm{HNO}_{3}$ and $\mathrm{NH} \mathrm{OH}$ of different concentrations were used and the $\mathrm{pH}$ of the solutions was determined using a laboratory $\mathrm{pH}$-meter type Agilent 3200P.

\section{Results and discussions}

HAP samples were tested to determine the adsorption capacity of $\mathrm{Cu}(\mathrm{II})$ ions from synthetic aqueous solutions and the influence of the retention parameters such as: solution $\mathrm{pH}$, contact time and $\mathrm{Cu}(\mathrm{II})$ ion concentration on the removal capacity. The two samples of HAP were used as adsorbent materials.

\section{pH effect on nano-HAP and micro-HAP-CaAlg adsorption capacity}

The adsorption of pollutants is mainly influenced by the $\mathrm{pH}$ of the solution due to the fact that $\mathrm{pH}$ affects the chemistry of the adsorbent and of the adsorbate in the solution. In the case of heavy metal ions, the solution's $\mathrm{pH}$ affects the speciation of the heavy metal ions in the solution and their availability. For adsorbents, the $\mathrm{pH}$ influences the properties and binding groups on the surface.

The effect of the solution's $p H$ was studied at an initial concentration of $100 \mathrm{mg} / \mathrm{L} \mathrm{Cu}(\mathrm{II})$ solution, the dose of adsorbents being $25 \mathrm{mg}$ and solution volume of $25 \mathrm{~mL}$ at room temperature (about $21^{\circ} \mathrm{C}$ ). The contact time between the two phases was $18 \mathrm{~h}$, a time considered sufficient to achieve the equilibrium. The $\mathrm{pH}$ range chosen was 2.5-6.5. $\mathrm{A} \mathrm{pH}$ value of more than 6.5 was not chosen because of the precipitation of $\mathrm{Cu}(\mathrm{II})$ ions as hydroxide can occur, and, as a result, a competition will occur between the removal of $\mathrm{Cu}(\mathrm{II})$ ions by adsorption on samples of HAP and precipitation.

The following equation has been considered to calculate the retention capacity of $\mathrm{Cu}(\mathrm{II})$ ions on HAP samples:

$$
\mathrm{Q}_{\mathrm{t}}=\frac{\left(\mathrm{C}_{0}-\mathrm{C}_{\mathrm{t}}\right) \mathrm{V}}{\mathrm{m}}
$$

where:

$\mathrm{Q}_{\text {- }}$ - is the $\mathrm{Cu}(\mathrm{II})$ ions quantity retained on adsorbent $(\mathrm{mg} / \mathrm{g})$;

$\mathrm{C}_{-}$- the initial concentration of $\mathrm{Cu}(\mathrm{II})$ ions in solution (mg/L);

$\mathrm{C}_{+}$- concentration of $\mathrm{Cu}$ (II) ions at time $\mathrm{t}$ (or at different $\mathrm{pH}$ values) $(\mathrm{mg} / \mathrm{L})$;

$\mathrm{V}$ - solution's volume $(\mathrm{L})$;

$m$ - the adsorbent's quantity (HAP samples) (g).

The experimental results obtained are presented in figure 1.

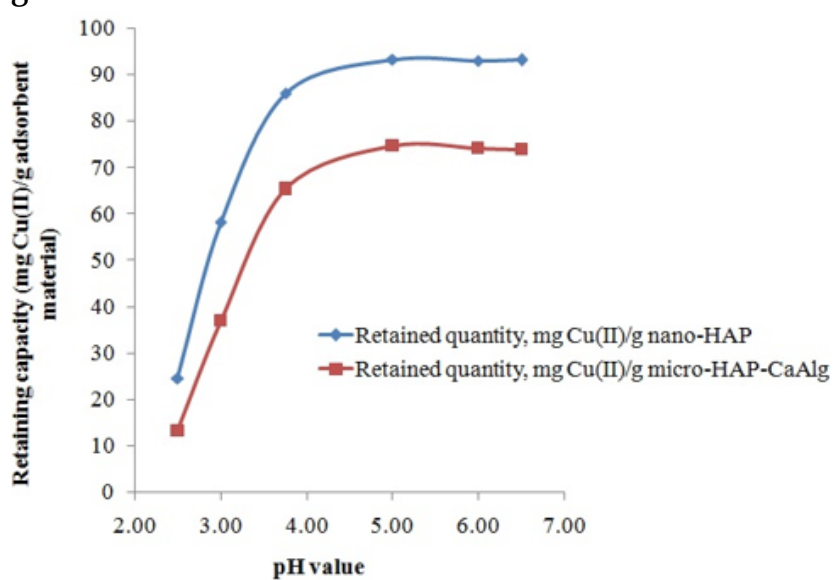

Fig. 1. The $\mathrm{pH}$ effect on $\mathrm{Cu}(\mathrm{II})$ sorption process on HAP samples

The main conclusions that can be drawn by analyzing the data presented in figure 1 are the following:

- Cu(II) ions removal capacity increases for both tested samples with increasing $\mathrm{pH}$ value to a $\mathrm{pH}$ value of 5 ;

- after the $p H$ value $=5$ there is a slight decrease of the retention capacity;

- at low $\mathrm{pH}$ value, the retention capacity is reduced due to the competition between the $\mathrm{Cu}(\mathrm{II})$ and the protons 
$\left(\mathrm{H}_{3} \mathrm{O}^{+}\right)$ions from the solution for occupying the active centers on the surface of the retaining material;

- the retention capacity varies in the order of nano-HAP> micro-HAP-CaAlg.

This variation in the retention capacity can be explained by the variation in the specific surface value between the nanometric and micrometric powders. The high value of the micro-HAP-CaAlg powder retention capacity is explained by the fact that calcium alginate adds more binding centers to the prepared composite. Calcium alginate is known as a high adsorbent and a good ion exchange material.

The optimal $\mathrm{pH}$ value for the tested materials is 5 . Consequently, the experiments on determining the influence of the other parameters were performed using $C$ (II) ion solutions at $\mathrm{pH}=5$.

The effect of contact time on nano-HAP and micro-HAPCaAlg adsorption capacity

The influence of contact time was studied in the range 0 - 720 min, using the $\mathrm{Cu}(\mathrm{II})$ solution of the concentration of $100 \mathrm{mg} / \mathrm{L}$, maintaining the adsorbent dose and the working temperature constant (fig. 2).

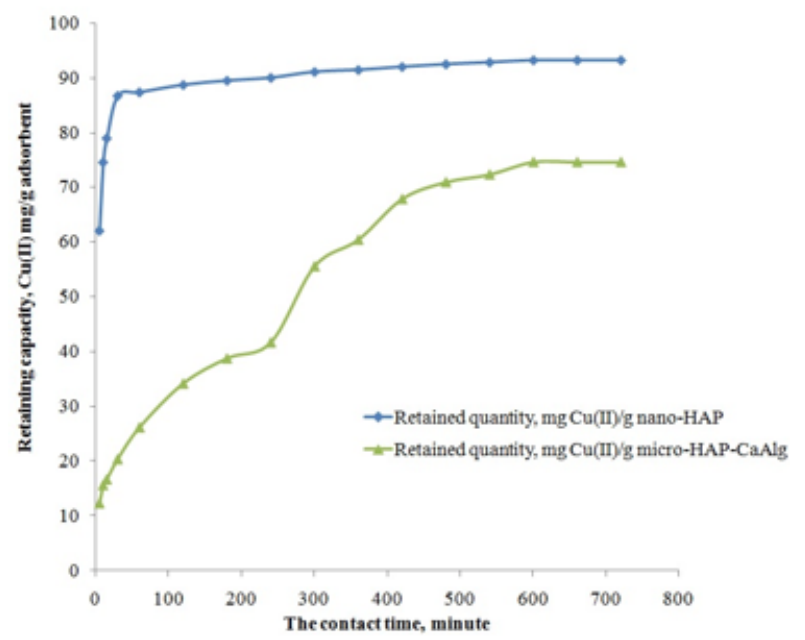

Fig. 2. The contact time effect on $\mathrm{Cu}(\mathrm{II})$ sorption process on HAP samples

Analyzing the data presented in figure 2, it can be seen that the adsorption rate for both HAP samples is rapid during the first 180 minutes and then continued at a slower rate from 180 to $600 \mathrm{~min}$. The equilibrium is reached after about $600 \mathrm{~min}$. Consequently, the optimal time for the removal of $\mathrm{Cu}(\mathrm{II})$ ions from the tested HAP samples is 600 min.

Both the optimal $\mathrm{pH}$ value and the time needed to achieve the equilibrium are important when it is desired to transform the experiments from laboratory to micro-pilot and even pilot scales.

\section{Adsorption isotherm}

The study of adsorption equilibrium and kinetics is fundamental to designing industrial reactors, to reducing running cost and to achieving insights into adsorption processes. Each adsorption/retention process is mathematically characterized using adsorption isotherms. These are mathematical expressions describing the relationship between the amount of dissolved substance adsorbed on the unit weight of the adsorbent and the concentration of the adsorbed in solution at a given temperature under steady conditions.

The most commonly used to characterize the sorption processes are Freundlich and Langmuir isotherms. The mathematical representation of the Freundlich model is expressed by equation (2) [34], and that of the Langmuir model by equation (3) [35]:

$$
Q=K_{f} \bullet C_{\varepsilon}^{1 / n}
$$

and

$$
\frac{\mathrm{C}_{\mathrm{e}}}{\mathrm{Q}_{\mathrm{e}}}=\frac{1}{\mathrm{Q}_{\max }} \cdot \mathrm{C}_{\mathrm{e}}+\frac{1}{\mathrm{Q}_{\max } \mathrm{K}_{\mathrm{L}}}
$$

where: $K_{f}$ and $1 / n$ represent the parameters of the adsorption isotherms (capacity and intensity) respectively; $\mathrm{K}$ is the parameter of the Langmuir model.

The Freundlich equation, linear in the logarithmic coordinates (4) is very often used for the processing of experimental data due to its simplicity.

$$
\ln Q=\ln K_{F}+\frac{1}{n} \ln C_{e}
$$

In order to determine the adsorption isotherm which characterizes the retention of $\mathrm{Cu}(\mathrm{II})$ ions on the HAP samples, batch experiments were performed and the data obtained were processed using the two isothermal models.

Copper (II) ion solutions were used: 5, 10, 25, 50, 75, $100 \mathrm{mg} / \mathrm{L}$, at $\mathrm{pH}=5$.

The experimental data obtained were correlated with the Freundlich and Langmuir isotherm models being presented in the following figures and table.

The data presented in the figures above were used to determine the parameters of the Langmuir and Freundlich

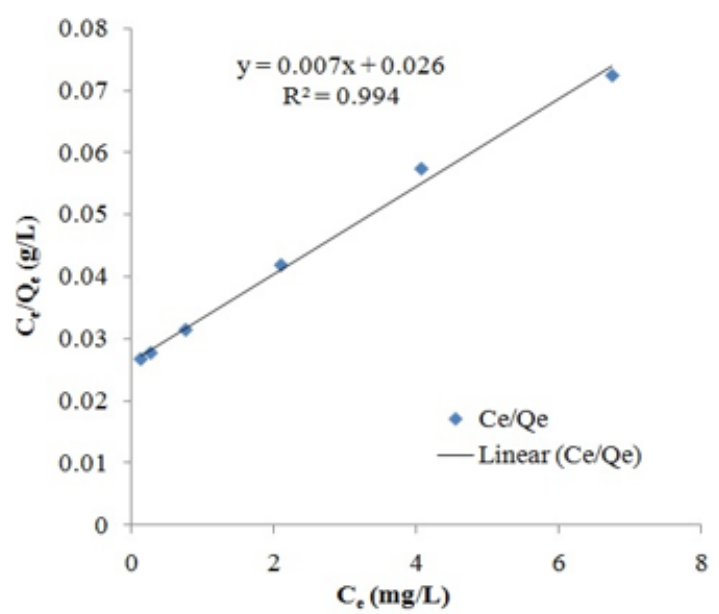

Fig. 3. The linearized Langmuir isotherm for the retention of $\mathrm{Cu}(\mathrm{II})$ ions onto nano-HAP

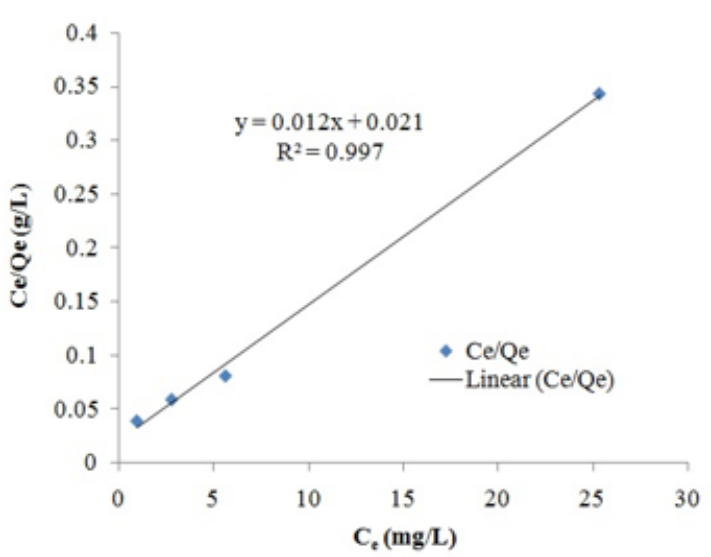

Fig. 4. The linearized Langmuir isotherm for the retention of $\mathrm{Cu}(\mathrm{II})$ ions onto micro-HAP-CaAlg 


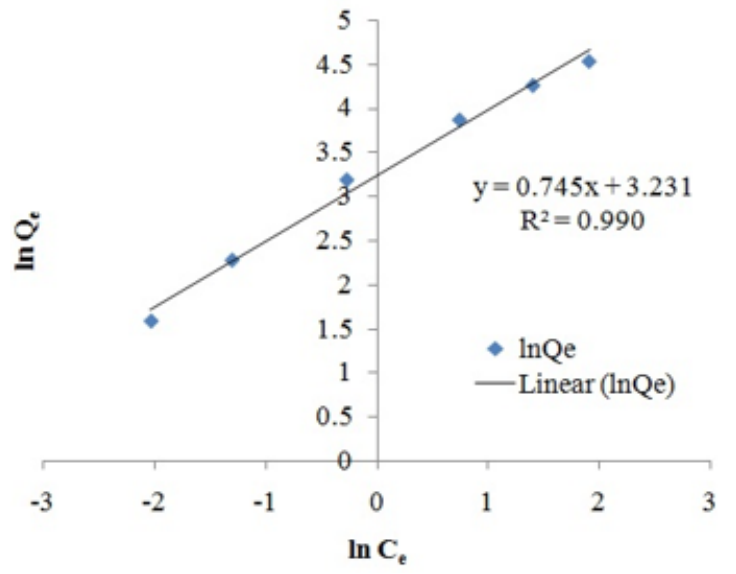

Fig.e 5. The linearized Freundlich isotherm for the retention of $\mathrm{Cu}(\mathrm{II})$ ions onto nano-HAP

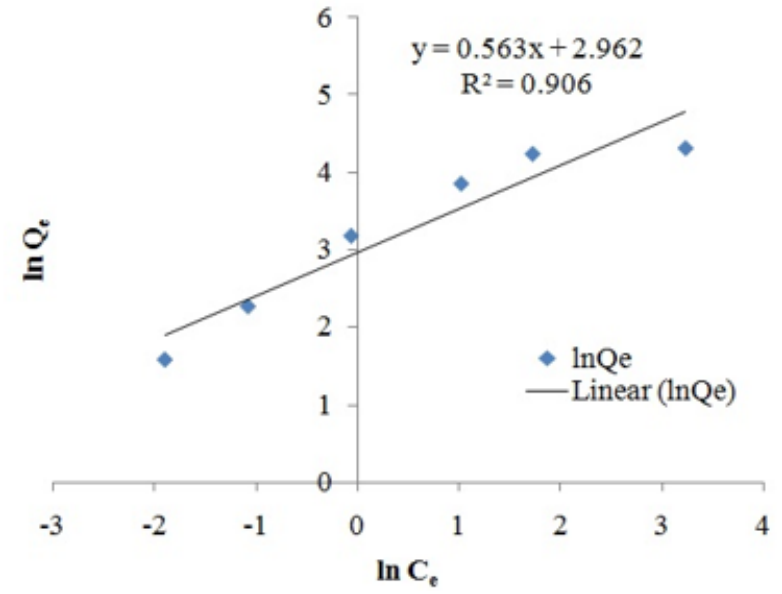

Fig. 6. The linearized Langmuir isotherm for the retention of $\mathrm{Cu}(\mathrm{II})$ ions onto micro-HAP-CaAlg

Table 1

PARAMETERS OF THE LANGMUIR AND FREUNDLICH ISOTHERMS CHARACTERISTIC OF THE ADSORPTION PROCESS OF CU(II) ON HAP SAMPLES

\begin{tabular}{|c|c|c|c|c|c|c|}
\hline \multirow{2}{*}{ Adsorbent } & \multicolumn{5}{|c|}{ Langmuir Parameters } & \multicolumn{3}{c|}{ Freundlich Parameters } \\
\cline { 2 - 7 } & $\mathrm{Q}_{\max }(\mathrm{mg} / \mathrm{g})$ & $\mathrm{K}_{\mathrm{L}}(\mathrm{L} / \mathrm{mg})$ & $\mathrm{R}^{2}$ & $\mathrm{~K}_{\mathrm{F}}(\mathrm{mg} / \mathrm{g})$ & $\mathrm{n}$ & $\mathrm{R}^{2}$ \\
\hline nano-HAP & 142.86 & 0.2651 & 0.9948 & 25.325 & 1.3412 & 0.9902 \\
\hline micro-HAP-CaAlg & 79.37 & 0.6000 & 0.9972 & 19.35 & 1.7749 & 0.9061 \\
\hline
\end{tabular}

models and the value of the correlation coefficient $R^{2}$ (table 1).

The values of coefficient correlation $\left(R^{2}\right)$ and $Q_{m}$ calculated values presented in table 1 confirm the validity of the Langmuir model. The values of the correlation coefficient $\mathrm{R}^{2}$ are closer to 1 for the Langmuir isothermal model for both tested materials.

The Langmuir model assumes that adsorption takes place in a monolayer on a homogeneous surface [35].

Kinetic study of the adsorption process of $\mathrm{CU}$ (II) ions on hydroxyapatite samples

The mechanism of any sorption process is controlled by kinetic models. The kinetic study is important for an adsorption process because it describes the speed of the pollutant removal process. In order to better understand the adsorption and kinetics mechanism, three kinetic models were selected, namely the pseudo-first-order kinetic model, the pseudo-second-order kinetic model, and the intraparticular diffusion to investigate the kinetics of the $\mathrm{Cu}(I I)$ by adsorption on HAP samples.

The pseudo-first-order kinetic model is based on the assumption that the rate of the adsorption process is proportional to the number of free active centers on the surface of the sorbent. This model is expressed in the Lagergren equation [36]:

$$
\frac{d Q_{t}}{d t}=k_{1}\left(Q_{e}-Q_{t}\right)
$$

where: $k_{1}$ is the speed constant of the sorption process by pseudo-first-order $\left(\mathrm{min}^{-1}\right)$ and g).

Qe, Qt is the equilibrium sorption capacity at time $(\mathrm{mg} /$

The linear form of the Lagergren equation is:

$$
\log \left(\mathrm{Q}_{\mathrm{e}}-\mathrm{Q}_{\mathrm{t}}\right)=\log \mathrm{Q}_{\mathrm{e}}-\frac{\mathrm{k}_{\mathrm{l}}}{2.303} \cdot \mathrm{t}
$$

where: $\mathrm{k}_{1}$ is the speed constant of the sorption process by pseudo-first-order ( $\mathrm{min}^{-1}$ ) and $\mathrm{Q}_{\mathrm{e}^{\prime}} \mathrm{Q}_{\mathrm{t}}$ is the quantity of $\mathrm{Cu}(\mathrm{II})$ retained at time $\mathrm{t}(\mathrm{mg} / \mathrm{g})$.

From the slope of the straight line and the intersection of the straight lines in the graph $\log (\mathrm{Q}$ e -Qt) versus $\mathrm{t}$, we

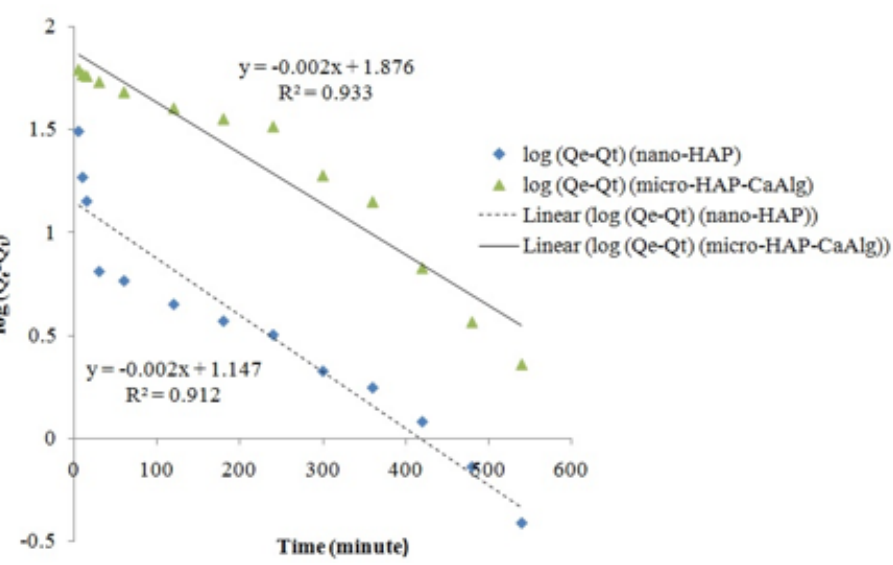

Fig. 7. Pseudo-first-order kinetics for sorption of $\mathrm{Cu}(\mathrm{II})$ on nanoHAP and micro-HAP-CaAlg

calculated $k_{1}$, the equilibrium sorption capacity $\left(Q_{\mathrm{e}}\right)$ and the correlation coefficient $R^{2}$.

The pseudo-second-order kinetic model is mathematically represented by the use of the equation $\mathrm{Ho}$ [37]:

$$
\frac{\mathrm{t}}{\mathrm{Q}_{\mathrm{t}}}=\frac{1}{\mathrm{k}_{2} \mathrm{Q}_{\mathrm{e}}^{2}}+\frac{\mathrm{t}}{\mathrm{Q}_{\mathrm{e}}}
$$

where $k_{2}$ is the rate constant of the of pseudo-secondorder kinetic sorption process ( $/ \mathrm{mg}$. $\mathrm{min}$ ). The experimental results obtained regarding the pseudosecond-order kinetic model are presented in figure 8.

The intraparticulate diffusion kinetic model is mathematically expressed by the equation introduced for the first time in 1962 by Weber and Morris [38]:

$$
\mathrm{Q}_{\mathrm{t}}=\mathrm{k}_{\mathrm{i}} \mathrm{t}^{0.5}+C
$$

where $k_{\text {is }}$ the intraparticulate diffusion rate constant $(\mathrm{mg} /$ $\left.\mathrm{g} \cdot \mathrm{min}^{0.5}\right)$, and $\mathrm{C}(\mathrm{mg} / \mathrm{g})$ is the intercept which gives indications about the thickness of the diffusion layer.

The linearized plots of $Q$ versus $t^{0.5}$ based on the experimental data obtained are shown in figure 9. 


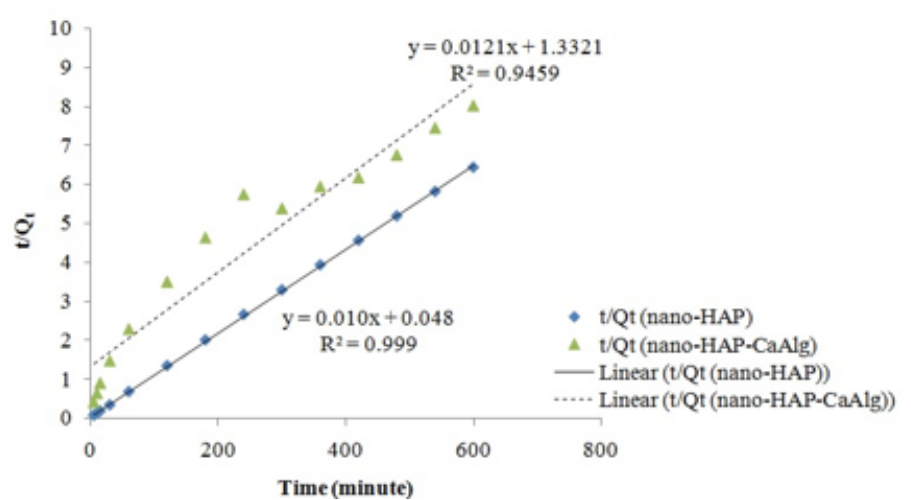

Fig. 8. Pseudo-second-order kinetics for sorption of $\mathrm{Cu}(\mathrm{II})$ on nano-HAP and micro-HAP-CaAlg

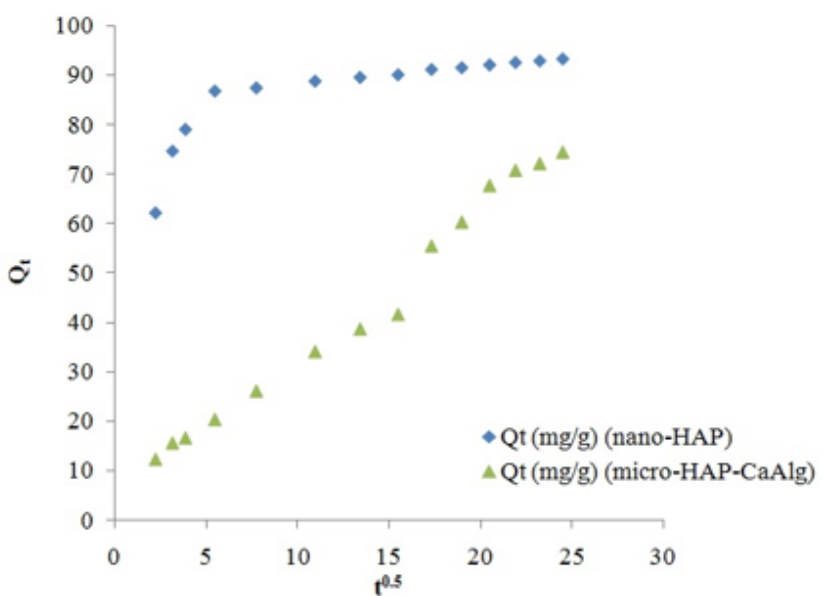

Fig. 9. Intraparticulate diffusion for $\mathrm{Cu}(\mathrm{II})$ sorption on nano-HAP and micro-HAP-CaAlg

Table 2

THE VALUES OF THE KINETIC PARAMETERS FOR THE ADSORPTION PROCESS OF CU(II) IONS ON HYDROXYAPATITE SAMPLES

\begin{tabular}{|c|c|c|c|c|}
\hline \multirow{2}{*}{ Adsorbent } & \multicolumn{2}{|c|}{ Pseudo-first-order kinetic } & \multicolumn{2}{c|}{ Pseudo-second-order kinetic } \\
\cline { 2 - 5 } & $\mathrm{k}_{1}\left(\mathrm{~min}^{-1}\right)$ & $\mathrm{R}^{2}$ & $\mathrm{k}$ ( $\mathrm{g} / \mathrm{mg} \cdot \mathrm{min})$ & $\mathrm{R}^{2}$ \\
\hline nano-HAP & $6.2181 \cdot 10^{-3}$ & 0.9122 & $2.3558 \cdot 10^{-3}$ & 0.9999 \\
\hline micro-HAP-CaAlg & $5.7575 \cdot 10^{-3}$ & 0.933 & $1.0991 \cdot 10^{-4}$ & 0.9459 \\
\hline
\end{tabular}

According to this model, if from the graphical representation of $Q_{\text {v }}$ versus $t^{0.5}$, a straight line is obtained, then the intraparticulate diffusion is involved in the adsorption process and if this line passes through the origin, the intraparticulate diffusion is the stage that controls the rate of the adsorption process respectively. If several lines are obtained from the graphic representation, it can be said that the adsorption process can take place in several stages.

As itcan be seen from figure 9, for both tested materials, it is possible to draw two lines from the graphical representation of Qt versus $t^{0.5}$ which can lead to the conclusion that the studied adsorption process could take place in two steps: the external diffusion followed by intraparticulate diffusion. Since the lines do not pass through the origin, we can not say that the adsorption process of the $\mathrm{Cu}$ (II) ions on the nano-HAP and the microHAP-CaAlg can be described using the kinetic diffusion intraparticulate model.

The data presented in figures 7, 8 were used to determine the parameters of pseudo-order kinetics models pseudo-order I and pseudo-order II by the study process studied and the values obtained are summarized in table 2.

It follows from the table 2 that the values of the correlation coefficient $\left(R^{2}\right)$ are closer to the value 1 for pseudo-second-order kinetics for both tested materials, indicating that the sorption process of $\mathrm{Cu}$ (II) from synthetic aqueous solutions can be described using the pseudosecond-order kinetic model. According to this model, the rate-determining step is chemisorption, not physical sorption or intraparticulate diffusion.

\section{Conclusions}

Batch experiments have been carried out to determine the potential application of egg shell derived hydroxyapatite in the recovery of $\mathrm{Cu}(\mathrm{II})$ from wastewater.

The main factors influencing the removal of $\mathrm{Cu}(\mathrm{II})$ by retention on HAP that were studied are: $\mathrm{pH}$, contact time and $\mathrm{Cu}(\mathrm{II})$ concentration in the initial solution. Our experimental results on the influence of $\mathrm{pH}$ on the $\mathrm{Cu}(\mathrm{II})$ retention process on hydroxyapatite samples demonstrated an optimal $p \mathrm{H}$ value of 5 for both tested samples.

The nano-HAP presents a higher adsorption capacity than micro-HAP-CaAlg, variation that can be explained based on the specific surface area values of nanometric and micrometric powders. The time required to achieve the equilibrium from experimental data is $600 \mathrm{~min}$ for all samples tested. The results obtained from the adsorption isotherm experiments describing the retention process studied showed that this process can be described using the Langmuir isothermal model according to which the adsorption takes place in a monolayer on a homogeneous surface.

The fact that the $\mathrm{Cu}(\mathrm{II})$ sorption kinetics can be described using the pseudo-second-order kinetic model suggests that the rate-determining step is chemisorption. The values of the retention capacity confirm that the tested powders (nano-HAP and micro-HAP-CaAlg) can be successfully used in the Cu(II) ion loaded water/ wastewater treatment/purification process.

\section{References}

1.CULITA, D.C., SIMONESCU, C.M., PATESCU, R.-E., STANICA, N., Rev Chim. (Bucharest) 69, no. 9, 2018, p. 2323.

2. PATESCU, R.-E., BUSUIOC, T.L., NECHIFOR, G., SIMONESCU, C.M., DELEANU, C., U.P.B. Sci. Bull. Series B, 79, Iss. 1, 2017, p. 119.

3. CULITA, D.C., SIMONESCU, C.M., PATESCU, R.-E., STANICA, N., PREDA, S., MUNTEANU, C., OPREA, O., J Inorg Organomet Polym Mater 17, no. 2, 2017, p.490.

4. BUSUIOC, T.L., SIMONESCU, C.M., PATESCU, R.-E., ONOSE, C., Rev Chim. (Bucharest) 67, no. 12, 2016, p. 2504.

5.PATESCU, R.-E., SIMONESCU, C.M., BUSUIOC, T.L., ONOSE, C., MELINESCU, A., Rev Chim. (Bucharest) 67, no. 10, 2016, p. 1899.

6. SIMONESCU, C.M., PATESCU, R.-E., BUSUIOC, T.L., ONOSE, C., MELINESCU, A., LILEA, V., Rev Chim. (Bucharest) 67, no. 8, 2016, p. 1498.

7. SIMONESCU, C.M., BUSUIOC, T.L., LILEA, V., DRAGNE, M., TARDEI, C., $15^{\text {th }}$ International Multidisciplinary Scientific Geoconference (SGEM), ECOLOGY, ECONOMICS, EDUCATION AND LEGISLATION, VOL I Book Series: International Multidisciplinary Scientific GeoConference, 2015, p. 169 DOI:10.5593/sgem2015B51 
8. SIMONESCU, C.M., MELINESCU, A., MELINTE, I., PATESCU, R.-E., DRAGNE, $M_{.}, 15^{\text {th }}$ International Multidisciplinary Scientific Geoconference (SGEM), ECOLOGY, ECONOMICS, EDUCATION AND LEGISLATION, VOL I Book Series: International Multidisciplinary Scientific GeoConference, 2015, p. 177, DOI:10.5593/sgem2015B51 9. SIMONESCU, C.M., FERDES, M., Pol J Environ Stud 21, 6, 2012, p. 1831.

10.SIMONESCU, C.M., DIMA, R., FERDES, M., MEGHEA, A., Rev Chim. (Bucharest) 63, no. 2, 2012, p. 224.

11. SIMONESCU, C.M., DINCA, O.-R., OPREA, O., CAPATINA, C., Rev Chim. (Bucharest) 62, no. 2, 2011, p. 183.

12. LIANG,W., ZHAN, L., PIAO, L., RÜSSEL, C., Mater Sci Eng B 176, 2011, p. 1010.

13. LATOCHA, J., WOJASINSKI, M., JURCZAK, K., GIERLOTKA, S., SOBIESZUK, P., CIACH, T., Chem Eng \& Process: Process Intensification 133, 2018, p. 221.

14. NOSRATI, H., MAMOORY, R.S., DABIR, F., PEREZ, M.C., RODRIGUEZ, M.A., SVEND LE, D.Q., BUNGER, C.., Mater Chem Phys 222, 2019, 251.

15. CATAUROA, M., BOLLINOA, F., TRANQUILLOA, E., TUFFIB, R., DELL'ERAC, A., VECCHIO CIPRIOTI, S., Ceram Int 45, 2019, p. 2835. 16.SABU, U., LOGESH, G., RASHAD, M., JOY, A., BALASUBRAMANIAN, M., Ceram Int 45, 2019, p. 6718.

17.SATHIYAVIMAL, S., VASANTHARAJ, S., LEWISOSCAR, F., PUGAZHENDHI, A., SUBASHKUMAR, R., IntJ Biol Macromol 129, 2019, p. 844.

18. FERRO, A.C., GUEDES, M., Mater Sci \& Eng C 97, 2019, p. 124.

19. XIA, X., SHEN, J., CAO, F., WANG, C., TANG, M., ZHANG, Q., WEl, S., J. Hazard Mater 368, 2019, p. 326.

20.NAKAGAWA, K., ARAI, Y., UMEZAKI, Y., YOSHIDA, A., KAJ IWARA, Y., AOYAGI, S., MATSUYAMA, H., SUGIYAMA, S., Mater Chem Phys 213, 2018, p. 183.

21. NIKOLAEVA, A.I., GOPINA, A.V., SEVERINA, A.V., RUDINA, V.N., MIRONOVB, M.A., DEZHKUNOV, N.V., Ultrason Sonochem 44, 2018, p. 390.
22. PAL, A., NASKER, P., PAUL, S., CHOWDHURY, A.R., SINHA, A., DAS, M., J Mechan Behav Biomed Mater 90, 2019, p. 328.

23. PAUL, S., PAL, A., CHOUDHURY, A.R., BODHAK, S., BALLA, V.K., SINHA, A., DAS, M., Ceram Int 43 no. 17, 2017, p. 15678.

24.LUNA-DOMINGUEZA, J.H., TÉLLEZ-J IMÉNEZA, H., HERNANDEZCOCOLETZIB, H., GARCIA-HERNÁNDEZC, M., MELO-BANDAC , J.A., NYGREN, H., Ceram Int 44, 2018, 22583.

25. MONDAL, S., HOANG, G., MANIVASAGAN, P., SANTHA MOORTHY, M., KIM, H.H., VY PHAN T.T., OH, J., Mater Chem Phys 228, 2019, p. 344.

26. NUNEZ, D., ELGUETA, E., VARAPRASAD, K., OYARZÚN, P., Mater Lett 230, 2018, p. 64.

27. BENSALAH, H., BEKHEET , M.F., YOUNSSI, S.A., OUAMMOU, M., GURLO, A., J Environ Chem Eng 6, 2018, p. 1347.

28. TAKEI, T., IMAZAWA, N., MIURA, A., KUMADA, N., OGIHARA, K., Powder Technol 237, 2013, p. 400.

29. HERMASSI, M., VALDERRAMA, C., DOSTA, J., CORTINA, J.L., BATIS, N.H., Chem Eng J 283, 2016, p. 572.

[30] YAN, Y., DONG, X., SUN, X., SUN, X., LI, J., SHEN, J., HAN, W., LIU, X., WANG, L., J Colloid Interf Sci 429, 2014, p. 68.

31. WU, S.-C., HSU, H.-C., HSU, S.-K., CHANG, Y.-C., HO, W.-F., Ceram Int 41, 2015, p. 10718.

32. GERGELY, G., WEBER, F., LUKACS, I., TOTH, A.L., HORVATH, Z.E., MIHALY, J., BALAZSI, C., Ceram Int 36, 2010, p. 803.

33. RAMESH, S., NATASHA, A.N., TAN, C.T., BANG, L.T., RAMESH, S., CHING C.Y., CHANDRAN, H., Ceram Int 42, 2016, p. 7824.

34.FREUNDLICH, H., HELLER, W., J. Am. Chem. Soc. 61, 1939, p. 2228. 35. LANGMUIR, I., J. Am. Chem. Soc. 40, 1918, p. 1361.

36. LAGERGREN, S., SVEN, K., Vettenskapsakad. Handl. 24, 1898, p. 1. 37. HO, Y.S., McKAY, G., Chem. Eng. J. 70, 1998, p. 115, https://doi.org/ 10.1016/S1385-8947(98)00076-X

38. WEBER, W.J., MORRIS, J.C., Advances in water pollution research: removal of biologically resistant pollutant from waste water by adsorption, in: Proceedings of $1^{\text {st }}$ International Conference on Water Pollution Symposium, vol. 2, Pergamon Press, Oxford, 1962, p. 231

Manuscript received: 16.02 .209 